\title{
PENGEMBANGAN PERANGKAT VISUALISASI KOMPUTER SISTEM AKUNTANSI BERBASIS ICT DENGAN MODEL PEMBELAJARAN BERPENDEKATAN CTL
}

\author{
Lucy Sri Musmini ${ }^{1}$, Gede Adi Yuniarta ${ }^{2}$ \\ 1, 2Jurusan Akuntansi Program Diploma III, Fakultas IImu Sosial \\ Universitas Pendidikan Ganesha \\ Singaraja, Indonesia \\ e-mail:musmini@yahoo.co.id; gdadi_ak@yahoo.co.id
}

\begin{abstract}
Abstrak
Penelitian ini dilatarbelakangi oleh pesatnya perkembangan ilmu pengetahuan dan teknologi yang terjadi dalam ilmu akuntansi. Tuntutan era global akan kemampauan professional mengharapkan tenaga kerja bidang akuntansi harus bisa menguasai kombinasi perkembangan ilmu akuntansi dan teknologi dalam melaksanakan tugas mereka sehari-hari. Apalagi perkembangan teknologi komputer berbasis Information and Communication Technology (ICT) yang sudah tidak membedakan jarak dalam penyusunan laporan keuangan akuntansi. Tujuan jangka panjang penelitian ini adalah terwujudnya Perangkat Visualisasi Komputer Sistem Akuntansi Berbasis Information and Communication Technology (ICT) Dengan Model Pembelajaran Berpendekatan Contextual Teaching And Learning yang valid, praktis, relevan dan mengikuti pesatnya perkembangan ilmu pengetahuan dan teknologi. Penelitian ini menggunakan model pengembangan perangkat pembelajaran Instructional Development Model (ID Model). Hasil penelitian menunjukkan bahwa: (1) Perangkat visualisasi sistem akuntansi yang menjadi produk penelitian sampai dengan tahun kedua ini menggambarkan bagaimana sistem akuntansi suatu perusahaan dengan berbasis kasus-kasus akuntansi yang diprioritaskan dalam bentuk: formulir, Jurnal, buku besar, buku besar pembantu dan laporan keuangan. Perangkat visualisasi sistem akuntansi ini baru berupa media visualisasi yang belum di link dengan perkembangan ICT. (2) Terkait pada kepuasan pengguna dalam perkuliahan secara general menunjukkan bahwa sebanyak $31,4 \%$ peserta kuliah merasa sangat puas dengan produk penelitian, sebagian besar peserta kuliah atau $61,6 \%$ merasa puas dengan pemanfaat perangkat visualisasi namun masih ada peserta sebanyak $7,1 \%$ merasa kurang puas dalam pemanfaatan perangkat visualisasi dalam rangka pembelajaran mata kuliah Sistem Akuntansi. Hal ini menunjukkan produk penelitian masih perlu untuk disempurnakan lagi baik dari segi substansi maupun dalam hal tampilan dan kepraktisan operasional.
\end{abstract}

Kata Kunci: Visualisasi komputer, sistem akuntansi, ICT dan Contextual Teaching And Learning 


\begin{abstract}
This research was motivated by the rapid development of science and technology that occurred in the science of accounting. Demands of the global era will expect professional workforce in accounting should be able to master the combination of accounting and technology development of science in their work everyday. Moreover, the development of computer technology-based Information and Communication Technology (ICT) which is no respecter of distance in the preparation of financial statements of accounting. The long term goal of this study was the realization of Visualization Tool Computer-Based Accounting System Information and Communication Technology (ICT) Learning Models With Contextual Teaching And Learning a valid, practical, relevant and to follow the rapid development of science and technology. This study uses a model of development learning Instructional Development Model (ID Model). The results showed that: (1) The visualization of the accounting system into the product until the second year of study illustrates how the accounting systems of an enterprise-based accounting cases are prioritized in the form: form, journal, general ledger, subsidiary ledgers and reports finance. Visualization device is a new accounting system in the form of visualization media that have not been in the link with the development of ICT. (2) Related to the satisfaction of users in a general course showed that study participants as much as $31.4 \%$ were very satisfied with the product of research, most participants go to college or $61.6 \%$ of users were satisfied with the device visualization but there is still a participant as much as $7.1 \%$ felt less satisfied in the use of visualization tools in order to study subjects Accounting System. This shows the product of research still needs to be refined again in terms of both substance and in terms of appearance and operational practicality.
\end{abstract}

Keywords: Visualization of computer systems, accounting, ICT and Contextual Teaching And Learning

\section{PENDAHULUAN}

Tenaga profesional di bidang akuntansi yang merupakan lulusan dari Jurusan Diploma III memerlukan kemampuan profesional termasuk dalam pemanfaatan teknologi untuk dapat tetap eksis di dalam mengahadapi tuntutan era global. Berbagai perkembangan teknologi sudah selayaknya dapat dimanfaatkan guna meningkatkan kompetensi di bidang akuntansi. Salah satu mata kuliah yang mengkaji kombinasi bidang ilmu akuntansi dan perkembangan teknologi adalah mata kuliah Sistem Akuntansi (Buku Pedoman Studi.2006). Penguasaan mahasiswa dalam mata kuliah ini ditujukan supaya mahasiswa dapat memahami sistem akuntansi yang diterapkan di berbagai bidang usaha termasuk perkembangan ilmu akuntansi yang dikaitkan dengan perkembangan teknologi guna memecahkan berbagai kasus akuntansi pada berbagai jenis bidang usaha yang ada baik untuk perusahaan jasa, dagang bahkan untuk perusahaan manufaktur (Profil Jurusan Diploma III Akuntansi. 2007).

Upaya yang mungkin dilaksanakan adalah dengan pola pembelajaran yang tepat dan memanfaatkan perkembangan teknologi salah satunya dengan pemanfaatan hasil pengembangan program komputer akuntansi terpadu. Program komputer akuntansi terpadu merupakan sebuah program yang dibuat untuk olah data akuntansi secara terpadu program komputer ini membantu mengolah data keuangan untuk diolah menjadi berbagai informasi keuangan. Pemanfaatan program komputer akuntansi terpadu disini adalah dalam 
bentuk visualisasi berbagai sistem akuntansi melalui program komputer sehingga peserta didik/ mahasiswa dapat lebih memahami konteks dari materi perkuliahan. Perkuliahan dikondisikan lebih menarik dengan visualisasi sistem akuntansi yang mengetengahkan materi perkuliahan secara kontektual (Contextual Teaching And Learning). Dengan pola pembelajaran Contextual Teaching And Learning dengan bantuan visualisasi komputer maka akan membantu dosen mengkaitkan materi (content) yang diajarkan dengan situasi dunia nyata dan mendorong mahasiswa membuat hubungan-hubungan antara pengetahuan yang dimilikinya dengan penerapannya dalam kehidupan mereka sehari-hari. Pengetahuan dan keterampilan mahasiswa diperoleh dari usaha siswa mengkonstruksi sendiri pengetahuan dan keterampilan baru ketika ia belajar. Landasan filosofi pembelajaran contextual adalah konstruktivisme, yaitu filosofi belajar yang menekankan bahwa belajar tidak hanya sekedar menghapal. Siswa harus mengkonstruksikan pengetahuan di benak mereka sendiri. Bahwa pengetahuan tidak dapat dipisah-pisahkan menjadi fakta-fakta atau proposisi yang terpisah, tetapi mencerminkan keterampilan yang dapat diterapkan. Dengan kombinasi pola pembelajaran Contextual Teaching And Learning dan visualisasi Sistem akuntansi dengan program komputer akuntansi terpadu maka proses pembelajaran diharapkan dapat menjadi lebih sistematis sehingga kualitas pembelajar dapat ditingkatkan. Tujuan dari penelitian ini adalah terwujudnya Perangkat Visualisasi Komputer Sistem Akuntansi Berbasis Information and Communication Technology (ICT) Dengan Model Pembelajaran Berpendekatan Contextual Teaching And
Learning yang valid, praktis, relevan dan mengikuti pesatnya perkembangan ilmu pengetahuan dan teknologi.

\section{METODE}

Dalam penelitian ini digunakan model pengembangan perangkat pembelajaran Instructional Development Model (ID Model) yang sering disebut model UNESCO(Arnyana, 2006). Tahap kegiatan dari model ini dibagi menjadi: Determinasi Masalah (Problem Determination), Desain (Design) dan Pengembangan (Development). Penelitian ini dilakukan di Universitas Pendidikan Ganesha Singaraja, tepatnya di Jurusan Akuntansi. Penelitian dilakukan selama tiga tahun yaitu mulai tahun 2010 sampai dengan tahun 2012.

\section{HASIL DAN PEMBAHASAN}

Kegiatan penelitian di tahun pertama difokuskan pada tahapan determinasi Masalah (Problem Determination) dan desain (design).

Dalam tahap ini kegiatan dikelompokkan dalam beberapa langkah yang dapat didiskripsikan sebagai berikut: (1) Identifikasi masalah: dalam tahap ini dilakukan identifikasi masalah-masalah yang timbul dalam pelaksanaan perkuliahan Sistem Akuntansi. Identifikasi masalah ini dikumpulkan berdasarkan pengalaman pengajaran mata kuliah yang sama pada waktu sebelumnya (pengalaman mengajar sebelumnya) selain itu identifikasi masalah ini juga diperoleh dari mahasiswa yang sudah menempuh mata kuliah bersangkutan. Dalam tahap ini masalah dalam perkuliahan Sistem Akuntansi dapat dikelompokkan dalam dua masalah utama yaitu: (1) Permasalahan teknis perkuliahan yang menyangkut penguasaan akan skill operasional komputer peserta didik yang

Jurnal Pendidikan Indonesia | 55 
tidak merata dan waktu perkuliahan yang dianggap kurang cukup untuk dapat menguasai materi perkuliahan yang padat dengan target penyelesaian kasus akuntansi baik untuk perusahaan jasa, dagang maupun manufaktur, (2) Permasalahan substansi perkuliahan yang meliputi dalam perkuliahan sistem akuntansi selayaknya mahasiswa sudah memahami semua substansi perkuliahan yang mendukung keilmuan akuntansi, seperti, akuntansi keuangan, akuntansi biaya, perpajakan, perbankan dan yang lainnya. Namun realitanya belum semua mata kuliah tersebut sudah ditempuh mahasiswa.

Dalam tahap identifikasi masalah permasalahan yang ternyata muncul dari perkuliahan yang terjadi adalah bahwa permasalahan dikelompokkan dalam dua kategori yaitu: permasalahan teknis pelaksanaan perkuliahan dan permasalahan substansi perkuliahan. Dalam permasalahan teknis perkuliahan ternyata penguasaan akan skill operasional komputer peserta didik yang tidak merata. Perlu adanya strategi pembelajaran yang mampu mengakomodasi sehingga mahasiswa lebih terbiasa dengan penguasaan perkembangan teknologi termasuk operasionalisasi perkembangan Information and Commonication Technology terutama dalam system jaringan (LAN). Sedangkan mengenai waktu perkuliahan yang dianggap kurang cukup memang mahasiswa memandang bahwa waktu perkuliahan yang disediakan tidak cukup untuk memahami materi yang harus mereka terima, dalam hal ini ada beberapa point yang bisa dicermati bahwa pertama mahasiswa masih memandang bahwa perkuliahan hanya berlangsung didalam kelas saja tanpa menyadari makna sesungguhnya dari sistem SKS (sistem kredit semester), hal kedua yang harus dicermati bahwa alokasi waktu yang tersedia memang harus dimanfaatkan semaksimal mungkin sehingga diperlukan sistematika (skenario) perkuliahan yang tepat disertai perangkat pembelajaran yang tepat pula. Dari hasil identifikasi permasalahan ini nampak jelas bahwa dalam teknis perkuliahan menunjukkan kurang sistematis.

Kasus akuntansi yang disiapkan diharapkan lebih mendekati kondisi riil di dunia usaha, lebih fleksible mengingat kondisi dunia usaha yang fleksible serta keterkaitan dengan bidang lain seperti asuransi, sistem perbankan, perpajakan dan lainnya. Kasus akuntansi yang dibahas juga diharapkan tidak kaku cenderung mendekati contoh - contoh yang ada dibuku saja namun sudah mengarah pada kondisi yang dapat meningkatkan kemampuan analisa dan kemampuan prediksi mahasiswa. Seiring dengan hal tersebut kertas kerja akuntansi yang disiapkan diharapkan juga disesuaikan secara khusus dengan kasus akuntansi yang dihadapi, kertas kerja selayaknya sistematis dan memiliki format terkini selayaknya yang berlaku di dunia kerja.

Penyiapan berbagai materi sistem akuntansi dengan fokus berbasis CTL. Materi difokuskan pada kasus-kasus akuntansi yang mencerminkan kegiatan riil di dunia kerja. Kasus akuntansi ini diharapkan akan dapat memancing meningkatnya kemampuan analisis dalam penyelesaian terhadap masalah sehingga akan menghasilkan perolehan pengetahuan dan keterampilan pemecahan masalah. Kasus yang disusun juga dikaitkan dengan disiplin lain seperti perbankan, pajak, asuransi, penggajian dan lainnya. Setelah itu dilakukan analisis hasil dengan melibatkan rekan seprofesi serta rekan ahli. 
Peran rekan seprofesi sesama Dosen Jurusan Akuntansi disini adalah memberikan masukan atas substansi perkuliahan mulai dari bagaimana penyusunan kasus- kasus akuntansi sehingga bisa mendekati kondisi rill di lapangan, bagaimana kasus akuntansi yang disusun bisa lebih komprehensif saling terkait dengan bidang lainnya seperti: asuransi, perbankan, bisnis dan perpajakan.

Setelah materi perkuliahan siap baru dimulai merancang perangkat visaualisasi sistem akuntansi. Perangkat visualisasi ini desain dengan menggunakan program Visual Basic. Secara sederhana perangkat visualisasi ini menggambarkan bagaimana sistem akuntansi suatu perusahaan dengan berbasis kasus-kasus akuntansi. Sistem akuntansi merupakan organisasi formulir, catatan, dan laporan yang di koordinasikan sedemikian rupa untuk menyediakan informasi keuangan yang dibutuhkan oleh manajemen guna memudahkan pengelolaan perusahaan. Dalam perangkat visualisasi ini elemenelemen pembentuk sistem akuntansi diprioritaskan dalam hal penyajiannya diantara elemen-elemen tersebut diataranya: (1) Formulir, merupakan dokumen yang digunakan untuk merekam terjadinya transaksi. Jurnal merupakan catatan akuntansi pertama yang digunakan untuk mencatat, mengklasifikasikan, dan meringkas data keuangan dan data lainnya. Sumber informasi pencatatan dalam jurnal ini adalah formulir. Dalam jurnal ini data keuangan untuk pertama kalinya diklasifikasikan menurut penggolongan yang sesuai dengan informasi yang akan disajikan dalam laporan keuangan. Dalam jurnal ini pula terdapat kegiatan peringkasan data, yang hasil peringkasannya (berupa jumlah rupiah transaksi tertentu) kemudian di-posting ke rekening yang bersangkutan dalam buku besar. Contoh jurnal adalah jurnal penerimaan kas, jurnal pembelian, jurnal penjualan, dan jurnal umum, (2) Buku besar (general ledger) terdiri dari rekeningrekening yang digunakan untuk meringkas data keuangan yang telah dicatat sebelumnya dalam jurnal. (3) Buku Pembantu, Jika data keuangan yang digolongkan dalam buku besar diperlukan rinciannya lebih lanjut, dapat dibentuk buku besar pembantu (subsidiary ledger), (4) Laporan keuangan, hasil akhir proses akuntansi adalah laporan keuangan yang dapat berupa neraca, laporan rugi laba, laporan arus kas, laporan harga pokok produksi, laporan biaya pemasaran, laporan harga pokok penjualan, daftar umur piutang, daftar utang yang akan dibayar, daftar saldo persediaan yang lambat penjualannya. Laporan berisi informasi yang merupakan keluaran sistem akuntansi.

Penelitian tahun kedua dilakukan pengembangan/penyempurnaan perangkat pembelajaran yang telah dilakukan pada tahap Desain. Kegiatan pengembangan yang dilakukan berupa mengembangkan Perangkat Visualisasi Komputer Sistem Akuntansi yang merupakan pengembangan program Komputer Akuntansi standar yang masih harus disempurnakan/dikembangkan sesuai dengan Standar Akuntansi Keuangan Indonesia dilengkapi dengan sistem operasional dalam penyelesaian kasuskasus akuntansi riil di dunia kerja. Pengembangan juga disertai dengan penyusunan bahan ajar dalam bentuk draf bahan ajar Sistem Akuntansi yang berisikan materi sistem akuntansi disertai manual dari perangkat Visualisasi Komputer Sistem Akuntansi dengan kasus-kasus akuntansi riil di dunia kerja beserta proses penyelesaian kasus (dapat dilihat pada lampiran produk penelitian ini). 
Setelah penyempurnaan perangkat selesai dilakukan maka tahapan terakhir yang dilakukan dalam penelitan di tahun kedua ini adalah uji coba pemanfaatan perangkat visualisasi dalam kegiatan pembelajaran yang sesungguhnya di kelas. Pada uji coba ini dilakukan simulasi penggunaan perangkat pada pembelajaran sesungguhnya dengan jumlah peserta sebanyak 106 orang. Pemanfaatan perangkat visualisasi digunakan dalam proses pembelajaran digunakan sebagai sarana pendukung dalam penguasaan substansi perkuliahan. Kebermanfaatan sarana visualisasi diuji dengan penyebaran kuisioner ke peserta kuliah. Kuisioner berisikan tentang kepuasan peserta terhadap pemanfaatan sarana visualisasi dalam proses pembelajaran yang meliputi: tampilan umum dan media yang digunakan, format sistematika, informasi yang terkandung (substansi dan relevansi keilmuan), serta kepraktisan dalam penggunaan. Hasil dari uji coba ini dapat dilihat pada tabel berikut ini:

Tabel 1

Kepuasan Peserta Dalam Rangka Pemanfaatan

Perangkat Visualisasi Sistem Akuntansi

\begin{tabular}{|c|c|c|c|c|c|c|}
\hline No. & Keterangan & $\begin{array}{l}\text { Sangat } \\
\text { puas }\end{array}$ & puas & $\begin{array}{l}\text { Kurang } \\
\text { Puas }\end{array}$ & $\begin{array}{l}\text { Tidak } \\
\text { puas }\end{array}$ & $\begin{array}{c}\text { Sangat } \\
\text { tidak } \\
\text { puas }\end{array}$ \\
\hline 1 & $\begin{array}{l}\text { Tampilan umum dan media yang } \\
\text { digunakan }\end{array}$ & $29,2 \%$ & $55,7 \%$ & $15,1 \%$ & - & - \\
\hline 2 & sistematika perangkat & $30,2 \%$ & $63,2 \%$ & $6,6 \%$ & - & - \\
\hline 3 & $\begin{array}{l}\text { Informasi yang terkandung (substansi } \\
\text { dan relevansi keilmuan) }\end{array}$ & $21,7 \%$ & $73,6 \%$ & $4,7 \%$ & - & - \\
\hline 4 & Kepraktisan dalam penggunaan & $44,3 \%$ & $53,8 \%$ & $1,9 \%$ & - & - \\
\hline & Rata -rata & $31,4 \%$ & $61,6 \%$ & $7,1 \%$ & & \\
\hline
\end{tabular}

Berdasarkan dari tabel 3.1 maka dapat diuraikan bahwa dari tampilan umum dan media yang digunakan menyatakan bahwa sebanyak $29,2 \%$ sangat puas dengan pemanfaatan perangkat visualisasi dan sebanyak $55,7 \%$ puas namun ada jumlah yang cukup besar yaitu $15,1 \%$ menyatakan kurang puas dengan tampilan umum dan media yang digunakan. Sedangkan untuk format sitematika perangkat visualisasi sebagian besar peserta yaitu 30,2\% puas, sebanyak $63,2 \%$ sangat puas dan masih ada sisanya sebanyak $6,6 \%$ merasa tidak puas dengan format sistematika perangkat visualisasi. Sedangkan untuk informasi yang terkandung (substansi dan relevansi keilmuan) sebanyak $21,7 \%$ sangat puas dengan inforrmasi yang terkandung dalam perangkat visualisasi, sebanyak $73,6 \%$ sangat puas dan sisanya $4,7 \%$ menyatakan kurang puas. Sedangkan untuk kepraktisan dalam penggunaan sebanyak $44,3 \%$ yang merasa sangat puas dan sebanyak $53,8 \%$ menyatakan sangat puas. Dari uraian tabel 3.1 ini maka secara general dapat disimpulkan bahwa sebagian peserta kuliah 
atau $61,6 \%$ merasa puas dengan pemanfaat perangkat visualisasi bahkan sebanyak 31,4 merasa sangat puas, namun masih ada peserta sebanyak $7,1 \%$ merasa kurang puas dalam pemanfaatan perangkat visualisasi dalam rangka pembelajaran mata kuliah Sistem Akuntansi.

Sedangkan untuk hasil dari evaluasi belajar implementasi dibatasi pada materi system akuntansi untuk perusahaan jasa dan dagang.uji coba hanya dilakukan selama setengah semester mengingat perkuliahan masih berlangsung sampai dengan bulan januari 2012. Evaluasi dibagi menjadi tiga bagian yaitu berdasarkan aktivitas, tugas-tugas dan ujian tengah semester.

Dalam pelaksanaan perkuliahan aktivitas mahasiswa diamati terutama dalam hal penguasaan akan skill komputer dan keaktifan dalam sesion diskusi serta kemampuan mempresentasikan hasil belajar termasuk dalam hal kehadiran mahasiswa. Penilaian untuk aktivitas mahasiswa ini dikelompokkan ke dalam dua sesion yaitu untuk sesion sistem akuntansi untuk perusahaan jasa, dan sistem akuntansi untuk perusahaan dagang. Hasil belajar tersebut dapat di lihat dalam tebel berikut ini:

Tabel 2

Hasil Belajar Dari Aktivitas Mahasiswa Di Kelas

\begin{tabular}{llllllll}
\hline & & \multicolumn{5}{c}{ Persentase jumlah mahasiswa dengan nilai } \\
\cline { 3 - 7 } No. & \multicolumn{1}{c}{ Keterangan } & $\mathbf{0 - 3 9}$ & $\mathbf{4 0 - 5 4}$ & $\mathbf{5 5 - 6 9}$ & $\mathbf{7 0 - 8 4}$ & $\mathbf{8 5 - 1 0 0}$ & Total \\
\hline 1 & $\begin{array}{l}\text { Sistem akuntansi untuk } \\
\text { perusahaan jasa }\end{array}$ & $0 \%$ & $0 \%$ & $1,9 \%$ & $63,2 \%$ & $34,9 \%$ & $100 \%$ \\
\hline 2 & $\begin{array}{l}\text { Sistem akuntansi untuk } \\
\text { perusahaan dagang }\end{array}$ & $0 \%$ & $0 \%$ & $3,8 \%$ & $52,9 \%$ & $43,3 \%$ & $100 \%$ \\
\hline
\end{tabular}

Sedangkan penilaian terhadap mahasiswa yang dilakukan terhadap tugastugas yang mereka kerjakan (dalam bentuk portofolio). Tagihan dalam bentuk portofolio ini juga dikatagorikan dalam dua kelompok yaitu untuk komputer akuntansi untuk perusahaan jasa, dan dagang. Di dalam masing-masing kelompok tersebut tagihan juga dikategorikan dalam tugas individu, kelompok dan perancangan sistem program akuntansi secara mandiri. Hasil belajar tersebut dapat dilihat dalam tabel berikut ini:

Tabel 3

Hasil Belajar Dari Tugas-tugas yang Dikumpulkan Mahasiswa

\begin{tabular}{llllllll}
\hline & & \multicolumn{6}{c}{ Persentase jumlah mahasiswa dengan nilai } \\
\cline { 3 - 7 } No. & \multicolumn{1}{c}{ Keterangan } & $\mathbf{0 - 3 9}$ & $\mathbf{4 0 - 5 4}$ & $\mathbf{5 5 - 6 9}$ & $\mathbf{7 0 - 8 4}$ & $\mathbf{8 5 - 1 0 0}$ & Total \\
\hline 1 & $\begin{array}{l}\text { Sistem akuntansi untuk } \\
\text { perusahaan jasa }\end{array}$ & $0 \%$ & $0 \%$ & $0 \%$ & $54,7 \%$ & $45,3 \%$ & $100 \%$ \\
\hline 2 & $\begin{array}{l}\text { Sistem akuntansi untuk } \\
\text { perusahaan dagang }\end{array}$ & $0 \%$ & $0 \%$ & $1,9 \%$ & $58,5 \%$ & $39,6 \%$ & $100 \%$ \\
\hline
\end{tabular}


Penilaian akhir terhadap hasil belajar mahasiswa baru sebatas pada pelaksanaan Ujian Tengah Semester dengan hasil dapat dilihat dalam tabel berikut ini:

Tabel 4

Hasil Evaluasi Mahasiswa

\begin{tabular}{|l|l|l|l|l|l|l|l|}
\hline \multirow{2}{*}{ No. } & Keterangan & \multicolumn{4}{c|}{ Persentase jumlah mahasiswa dengan nilai } \\
\cline { 3 - 7 } & & $\mathbf{0 - 3 9}$ & $\mathbf{4 0 - 5 4}$ & $\mathbf{5 5 - 6 9}$ & $\mathbf{7 0 - 8 4}$ & $\mathbf{8 5 - 1 0 0}$ & \multicolumn{1}{|c|}{ Total } \\
\hline 1 & Ujian Tengah Semester & $0 \%$ & $0 \%$ & $0,9 \%$ & $54,7 \%$ & $44,3 \%$ & $100 \%$ \\
\hline 2 & Ujian Akhir Semester & $0 \%$ & $0 \%$ & $0 \%$ & $0 \%$ & $0 \%$ & $0 \%$ \\
\hline
\end{tabular}

Pesatnya perkembangan ilmu pengetahuan dan teknologi telah menuntut pada kemampuan professional dosen dalam mencetak sarjana siap pakai dan mampu beradaptasi dengan perkembangan teknologi yang terjadi. Aktivitas pembelajaran di lembaga-lembaga pendidikan tinggi tidak hanya difokuskan pada upaya mendapatkan pengetahuan secara teori sebanyakbanyaknya, melainkan juga harus mampu memanfaatkan perkembangan teknologi guna meningkatkan kualitas pembelajaran. Peningkatan kualitas pembelajaran diharapkan akan dapat menciptakan kemampuan profesional di bidang tertentu yang sangat penting artinya bagi pelajar dan masa depannya. Namun perkembangan teknologi yang semakin meningkat dari waktu - kewaktu menuntut semakin kompleksnya akan pemahaman kombinasi dari bidang ilmu dan perkembangan teknologi yang menyertainya.

Perkembangan teknologi telah merambah berbagai aspek kehidupan, tidak terkecuali dalam bidang akuntansi. ditambah lagi system informasi yang semakin tidak terbatas termasuk Information and Communication Technology (ICT) yang telah melenyapkan keterbatasan jarak dalam penyelesaian kasus-kasus akuntansi. Sarjana akuntansi diharapkan sudah dapat memanfaatkan perkembangan teknologi ini dengan mengkombinasikannya dengan bidang akuntansi. Namun usaha tersebut tidaklah semudah yang dikira. Banyak hal yang mesti disiapkan mulai dari ketersiapan dosen, fasilitas, perangkat dan media pembelajaran, termasuk kesiapan peserta didik dalam menguasai kombinasi perkembangan ilmu pengetahuan dan teknologi ditambah lagi kemampuan mengkaitkannya dengan permasalahan riil akuntansi yang terjadi di dunia usaha.

Berdasarkan hasil penelitian maka ada beberapa hal yang dapat dibahas dalam penelitian ini diantaranya terkait dengan isu tentang masalah pentingnya penelitian ini dilakukan adalah dapat dilihat dari kontribusi positif terhadap dunia pendidikan terutama di dalam menyiapkan tenaga professional di bidang akuntansi khususnya dalam menyiapkan tenaga siap pakai yang mampu mengkombinasikan perkembangan ilmu pengetahuan dengan perkembangan teknologi. Bila lebih diditailkan lagi maka kontribusi ini bisa meliputi; (1) Kontribusi dalam menunjang pembangunan bidang pendidikan dan (2) Kontribusi bagi pengembangan institusi, khususnya dalam rangka ikut berperan dalam pengembangan ilmu pengetahuan dan teknologi.

Produk penelitian ini berupa perangkat visualisasi sistem akuntansi yang menggambarkan bagaimana sistem akuntansi suatu perusahaan dengan berbasis kasus-kasus akuntansi. Dalam 
perangkat visualisasi ini elemen- elemen pembentuk sistem akuntansi diprioritaskan dalam hal penyajiannya diantara elemenelemen tersebut diataranya: formulir, Jurnal, buku besar, buku besar pembantu dan laporan keuangan. Kelima komponen pembentuk sistem ini dituangkan dalam perangkat visualisasi. Perangcangan perangkat visualisasi sistem akuntansi di tahun kedua sudah mengalami penyempurnaan penambahan materi akuntansi bila dibandingkan dengan produk di tahun pertama. Produk penelitian ini juga sudah mulai diuji coba dalam pembelajaran untuk memperoleh respon peserta kuliah dan penyempurnaan substansi.

Terkait dengan temuan penelitian ditahun kedua terfokus pada kepuasan pengguna dalam perkuliahan secara general dapat disimpulkan bahwa sebanyak 31,4\% peserta kuliah/responden merasa sangat puas dengan produk penelitian, sebagian besar peserta kuliah atau $61,6 \%$ merasa puas dengan pemanfaat perangkat visualisasi namun masih ada peserta sebanyak $7,1 \%$ merasa kurang puas dalam pemanfaatan perangkat visualisasi dalam rangka pembelajaran mata kuliah Sistem Akuntansi. Hal ini menunjukkan produk penelitian masih perlu untuk disempurnakan lagi baik dari segi substansi maupun dalam hal tampilan dan kepraktisan operasional. Terkait dengan hasil belajar secara general juga dapat disimpulkan bahwa pemahaman peserta sudah mencapai tingkat penguasaan diatas $70 \%$ keatas. (table 5.2 , table 5.3 dan table 5.4)

Berdasarkan hasil penelitian dan pembahasan maka ada beberapa hal yang dapat dijadikan implikasi penelitian diantaranya: (1) dari hasil tingkat kepuasan pengguna dan hasil belajar menunjukkan bahwa perangkat visualisasi system akuntansi masih perlu untuk disempurnakan lagi untuk pelaksanaan tahun berikutnya terutama terkait dengan: tampilan umum dan media yang digunakan, sitematika dan substansi perangkat. (2) Perangkat visualisasi yang merupakan produk penelitian sampai dengan tahun kedua ini belum di link dengan perkembangan ICT, sehingga untuk penelitian tahun berikutnya setelah secara substansi dan tampilan perangkat ini sudah dianggap cukup baik baru disempurnakan lagi menjadi perangkat visualisasi berbasis ICT.

\section{SIMPULAN DAN SARAN}

Berdasarkan dari hasil penelitian dan pembahasan maka dapat disimpulkan bahwa: (1) Perangkat visualisasi sistem akuntansi yang menjadi produk penelitian sampai dengan tahun kedua ini menggambarkan bagaimana sistem akuntansi suatu perusahaan dengan berbasis kasus-kasus akuntansi. Dalam perangkat visualisasi ini elemen- elemen pembentuk sistem akuntansi diprioritaskan dalam hal penyajiannya diantara elemenelemen tersebut diataranya: formulir, Jurnal, buku besar, buku besar pembantu dan laporan keuangan. Perancangan perangkat visualisasi sistem akuntansi sampai dengan ditahun kedua baru berupa media visualisasi yang belum di link dengan perkembangan ICT namun media ini harus diuji coba dulu dalam pembelajaran untuk memperoleh respon peserta kuliah dan penyempurnaan substansi. (2) Penelitian ditahun kedua terfokus pada kepuasan pengguna dalam perkuliahan secara general yang menunjukkan bahwa sebanyak $31,4 \%$ peserta kuliah merasa sangat puas dengan produk penelitian, sebagian besar peserta kuliah atau $61,6 \%$ merasa puas dengan pemanfaat perangkat visualisasi namun 
masih ada peserta sebanyak $7,1 \%$ merasa kurang puas dalam pemanfaatan perangkat visualisasi dalam rangka pembelajaran mata kuliah Sistem Akuntansi. Hal ini menunjukkan produk penelitian masih perlu untuk disempurnakan lagi baik dari segi substansi maupun dalam hal tampilan dan kepraktisan operasional. Terkait dengan hasil belajar secara general juga dapat disimpulkan bahwa pemahaman peserta sudah mencapai tingkat penguasaan diatas $70 \%$ keatas.

\section{DAFTAR PUSTAKA}

Albertus O. 2001, Menguasai MYOB Accounting 10 dan Time Billing. Jakarta: Elex Media Komputindo.

AL. Haryono J. 2001. Dasar - dasar Akuntansi. Jilid 1. Yogyakarta: Bagian Penerbitan STIE YKPN.

AL. Haryono J. 2001. Dasar - dasar Akuntansi, Jilid 2. Yogyakarta: Bagian Penerbitan STIE YKPN.

Arens, Alvin A, Randal J. E and Mark S. B. 2003. Auditing and Assurance Service an Integrated Approach. Ninth Edition. New Jersey: Person Education Inc.

Arens, Alvin A dan James K. L. 1994. Auditing Pendekatan Terpadu. [Adaptasi: Amir Abadi Jusuf]. Jakarta: Salemba Empat.

Arnyana. 2005. Pengaruh Penerapan Model PBL dipandu Strategi Kooperatif Terhadap Kecakapan Berfikir Kritis Siswa SMA Pada Mata Pelajaran Biologi. Singaraja. Jurnal Pendidikan dan Pengajaran, 38, 646-667

Arnyana. $\quad 2006 . \quad$ Model-model Pengembangan Perangkat Pembelajaran. Singaraja. Makalah yang disampaikan dalam Lokakaraya Model-model pembelajaran Unit P3AI IKIP Negeri Singaraja

Candiasa. 2005.Teknologi Informasi Dan Komunikasi Di Sekolah Menengah Srategi Pembelajaran dan Instrumen Evaluasinya. Singaraja. Jurnal
Pendidikan Dan Pengajaran, 38 no.4, 561-577

Carspecken, P.F. 1996. Critical Etnography in Educational Research. A Theoritical and Practical Guides. NY and London: Routledge.

Cooper. 1990. The implementation of moral paradigm in our education. KanadaNew Jersey: Bacon, Ltd.

Degeng, N.S. 2003. Bisa Ciptakan Bangsa Buruh, Jawa Post. HIm.30.

Direktorat Pembinaan Pendidikan Tenaga Kependidikan. 2006. Pedoman Penyusunan Usulan dan Laporan Penelitian Untuk Peningkatan Kualitas Pembelajaran Di LPTK (PPKP). Jakarta: Departemen Pendidikan Nasional

Gagne, R M.; Briggs, Leslie J.; dan Wager, Walter W. 1988. Principles of Instructional Design. 3rd. Edition, New York: Holt Rinehart and Winston, Inc..

Galbreath,J. 1999. Preparing the 21 Century Worker: The Link Between ComputerBased Tecnology And Future Skill Sets. Educational Technology. Desember 1999

Gijselaers, W.H. (1996). Connecting Problem-Based Practices with Educational Theory. New Direction for Teaching and Learning. No.68.

Hansen, M. 2004. Management Accounting. Jakarta: Salemba Empat

Hendriksen, E.S. (Marianus Sinaga, Editor). 1996. Teori Akuntansi. Edisi ke- 4. Jakarta: Erlangga.

Hendriksen, V.B. 2000. Teori Akunting. Edisi Kelima. Batam: Penerbit Interaksa

Ibrahim, M. 2001. Model Pengembangan Perangkat Pembelajaran Menurut Kemp \& Thiagarajan. Surabaya: Universitas Negeri Surabaya

Ibrahim,M. dan Nur, Moh. 2004. Pengajaran Berbasis Masalah. Surabaya: University Press.

Ikatan Akuntan Indonesia. 2002. Standar Akuntansi Keuangan. Jakarta: Salemba Empat. 
Imam G., John C. 2002. Statistik Non Parametrik. Semarang: Badan Penerbit Universitas Diponegoro

Imam G. A. C,. 2003. Teori Akuntansi. Edisi Revisi, Semarang: Badan penerbit Universitas Diponegoro

Johar A. 2000. M.Y.O.B Accounting Plus 9.x dan V.10. Jakarta: Elex Media Komputindo

Johar A. 2000. Trik Akuntansi dengan Dac Easy Accounting \& MYOB Accounting. Jakarta: Elex Media Komputindo.

Johar A. 2001. Mengupas tuntas MYOB Accounting Multi Currency. Jakarta: Elex Media Komputindo

Johar A. 2004. Aplikasi Excel Dalam Studi Akuntansi dan Manajemen Keuangan. Jakarta: Elex Media Komputindo.

Johnson. 2002. Joining Together: The Principles of Cooperative Learning. USA: Open University Press.

Johnson, E.B. 2002. Contextual Teching and Learning. California: Corwin Press.

Joyce, Bruce and Marsha Weil. 1986. Models of Teaching. (Third Edition). Englewood Cliffs. N.J.: Prentice-Hall, Inc.

Kagan, R.H and James B. 1999. Learning Revolution: New Paradigm in Teaching Secondary Students. Jornal of Education. No.101. Vol. 10 January 2000. http://kagan.olam.asu.edu/epaa

Kam, V. 1990. Accounting Theory. Second Edition. John Wiley and Sons Inc.

Keiso, Donald E dan Weygad, Jerry J. (1995). Intermediate Accounting. Edisi ke-10 Jakarta: Penerbit Erlangga.

Knirk, F.G and Gustafon, K.L. 1986. Instructional Technology: A Systematic Approach To Education. New York: CBS College Publishing

Kusnadi, Lukman S., Kertahadi. 2001. Teori Akuntansi. Malang: Universitas Brawijaya

Mulyadi. 1997. Sistem Informasi Akuntansi. Yogyakarta: BPFE
Mulyasa. 2003. Kurikulum Berbasis Kompetensi; Konsep, Karakteristik, dan Implementasi. Bandung: Remaja Rosdakarya.

Puskur. (2003). Kurikulum Berbasis Kelas. Avalailable at: http/www: info@puskur.or.id, blitbang@cbn.net.id

Puskur. 2003. Otonomi Pendidikan dan Kurikulum Berbasis Kelas. Avalailable at: http/www: info@puskur.or.id, blitbang@cbn.net.id

Puskur. 2003. Pengelolaan Kurikulum Berbasis Kelas. Avalailable at: http/www:_info@puskur.or.id, blitbang@cbn.net.id

Rahyuda, Nurcaya. 1999. Pengantar Aplikasi Komputer. Denpasar: Fakultas Ekonomi Universitas Udayana.

Ratna, W.D. 1996. Teori-Teori Belajar. Jakarta: Erlangga

Ricard I. A. 2006. Learning to teach with online Learning Center Card With Power Web and CR-ROM: Mc. Graw Hill

Rindell, A.J.A.1999. Appying Inquiry-Based dan Cooperative Group Learning Strategies to Promote Critical Thinking. Journal Of College Science Teaching (JCST). 28(3): 203-207

Siti,M. dan Suheimi, S. 2005. Implementasi Pembelajaran Kontektual Melalui Model Pembelajaran Kooperatif berbantuan Buku Ajar Untuk Meningkatkan Aktivitas dan Hasil Belajar Kimia Dasar Mahasiswa Jurusan IImu Keolahragaan. Singaraja. Jurnal Pendidikan Dan Pengajaran, 38 no.3, 397-418

Soemarso S.R. 1999. Akuntansi Suatu Pengantar , Buku satu. Jakarta: Rineka Cipta.

Soemarso S.R. 1999. Akuntansi Suatu Pengantar. Buku dua. Jakarta: Rineka Cipta

Sugiyono, Eri W. 2004. Statistika untuk Penelitian. Jakarta: Alfabeta

Jurnal Pendidikan Indonesia | 63 
Suharsono, N. 1991. Model Pembelajaran Pemecahan Masalah: Penerapan di Bidang Bisnis. Disertasi tidak diterbitkan. Program Pascasarjana IKIP Malang.

Suharsono, N., Ketut Rindjin, Made Japa. (1994). Respons dan Tindakan Mahasiswa di Kelas. Studi Eksploratoris di STKIP Singaraja. Laporan Hasil Penelitian. tidak diterbitkan.

Suharsono, N . 1998. Penerapan Model Pembelajaran Pemecahan Masalah untuk Mengembangkan Kemampuan Berpikir dan Bernalar Mahasiswa. Singaraja. Laporan Hasil Penelitian, tidak diterbitkan.

Sutrisno, H. 2004. Metodelogi Research. Yogyakarta: Penerbit Andi

UNESCO. 1996. What Makes a Good Teacher? Children Speak Their Minds. Paris.

UNESCO. 1998. World Education Reports: Teachers and Teaching in a Changing World. Paris.

Universitas Pendidikan Ganesha Singaraja. 2006. Profil Jurusan Akuntansi. Singaraja.

Universitas Pendidikan Ganesha Singaraja. 2004. Buku Pedoman Studi Tahun 2002. Edisi Revisi. Singaraja. 